ISSN: 2302-8556

\title{
Manajemen Laba Memoderasi Pengaruh Perubahan Laba, Perubahan Nilai Buku Ekuitas pada Relevansi Nilai Informasi Akuntansi
}

\author{
I Gede Ardian Andriawan ${ }^{1}$ \\ I Dewa Nyoman Wiratmaja ${ }^{2}$ \\ ${ }^{1,2}$ Fakultas Ekonomi dan Bisnis Universitas Udayana (Unud), Bali, Indonesia \\ e-mail:ardianandriawan@gmail.com
}

\begin{abstract}
ABSTRAK
Tujuan penelitian adalah membuktikan manajemen laba memoderasi pengaruh perubahan laba dan perubahan nilai buku ekuitas pada relevansi nilai informasi akuntansi. Analisis data menggunakan analisis regresi berganda serta moderated regression analysis digunakan untuk menguji manajemen laba dalam memoderasi pengaruh perubahan laba dan perubahan nilai buku ekuitas pada relevansi nilai informasi akuntansi. Hasil dari penelitian adalah perubahan laba dan perubahan nilai buku ekuitas berpengaruh positif pada relevansi nilai informasi akuntansi, selain itu manajemen laba memperlemah pengaruh perubahan laba dan perubahan nilai buku ekuitas pada relevansi nilai informasi akuntansi. Implikasi penelitian adalah mendukung dan menambah bukti empiris mengenai teori keagenan, dan kontribusi positif bagi pengguna laporan keuangan .
\end{abstract}

Kata Kunci : Relevansi nilai, laba, nilai buku ekuitas, manajemen laba

\begin{abstract}
The research objective is to prove earnings management moderates the effect of earnings changes and changes in equity book values on the relevance of the value of accounting information. Data analysis using multiple regression analysis and moderated regression analysis is used to test earnings management in moderating the effect of earnings changes and changes in equity book values on the relevance of the value of accounting information. The results of the study are changes in earnings and changes in the book value of equity have a positive effect on the relevance of the value of accounting information, in addition earnings management weakens the influence of changes in earnings and changes in equity book values on the relevance of accounting information. The research implications are supporting and adding empirical evidence about agency theory, and positive contributions to users of financial statements.
\end{abstract}

Keywords: Value relevance, profit, equity book value, earnings management

\section{PENDAHULUAN}

Seorang investor membutuhkan analisis dan pemahaman atas informasi dalam melakukan pengambilan keputusan sehingga keputusan investasi yang diambil dapat memberikan keuntungan yang optimal. Pengambilan keputusan ini berkaitan dengan pemilihan portofolio investasi yang paling menguntungkan dengan tingkat risiko tertentu. Informasi dapat mengurangi ketidakpastian yang 
terjadi, sehingga keputusan yang diambil diharapkan sesuai untuk mencapai tujuan yang diinginkan.

Laporan keuangan merupakan catatan informasi keuangan suatu perusahaan dalam periode akuntansi yang berguna untuk mengetahui kinerja suatu perusahaan. Informasi ini bisa digunakan bagi pihak internal seperti manajemen, karyawan dan juga pihak eksternal seperti investor, kreditor, maupun pemerintah. Tujuan laporan keuangan adalah untuk memberikan informasi mengenai posisi keuangan, kinerja keuangan, dan arus kas entitas yang bermanfaat bagi sebagian besar pengguna laporan keuangan dalam pembuatan suatu keputusan (PSAK No. 1, 2017:09). Karakteristik kualitatif laporan keuangan menurut FASB adalah relevan dan reliabel. Relevan merupakan kemampuan informasi untuk membantu investor, kreditor, dan pemakai lain dalam menyusun prediksi-prediksi tentang beberapa munculan (outcomes) dari kejadian masa lalu, sekarang, dan masa datang atau dalam mengkonfirmasi atau mengkoreksi harapanharapannya(Suwardjono, 2017:167). Informasi akuntansi dikatakan relevan dengan keputusan investasi apabila dapat mempengaruhi keputusan dengan menguatkan atau mengubah pengharapan para pengambil keputusan. Suatu informasi dikatakan relevan apabila memenuhi tiga unsur penting yaitu memiliki nilai prediktif, umpan balik, dan tepat waktu. Laporan keuangan menyajikan informasi yang relevan dan reliabel dapat memberikan pemakai laporan keuangan keyakinan bahwa informasi yang disajikan merupakan infromasi yang valid yang digunakan untuk membuat beberapa alternatif keputusan yang ada. 
Relevansi nilai merupakan salah satu aspek untuk mengukur kualitas informasi akuntansi, yaitu kemampuan suatu informasi yang disajikan dalam laporan keuangan untuk menggambarkan nilai suatu perusahaan(Kargin, 2013). Informasi akuntansi memiliki relevansi nilai apabila informasi akuntansi tersebut dapat dijadikan dasar untuk memprediksi nilai pasar perusahaan(Barthet al., 2001). Penelitian mengenai relevansi nilai menjadi penting karena terdapat klaim yang menyatakan bahwa laporan keuangan berbasis kos historis telah kehilangan sebagian besar relevansinya bagi investor yang diakibatkan oleh perubahan besarbesaran dalam perekonomian, yaitu dari perekonomian industrial ke prekonomian berteknologi tinggi dan berorientasi jasa (Francis \& Schipper, 1999).

Informasi akuntansi pada laporan keuangan yang sering digunakan sebagai alat untuk mengukur kinerja perusahaan adalah laba dan nilai buku (Kusuma, 2006). Informasi perubahan laba dapat digunakan sebagai pertimbangan oleh investor dalam pengambilan keputusan investasi. Perubahan laba yang diperoleh perusahaan sangat penting bagi pemakai laporan keuangan karena dengan mengetahui perubahan laba, mereka dapat menentukan apakah terdapat peningkatan atau penurunan kinerja keuangan suatu perusahaan yang pada akhirnya akan meningkatkan perhatian pengguna laporan keuangan (Agustina \& Silvia, 2012). Nilai buku ekuitas dapat memberikan informasi mengenai besarnya nilai sumber daya yang telah dimiliki suatu perusahaan dan mengetahui seberapa besar jaminan yang diberikan perusahaan kepada investor. Jika nilai buku meningkat, maka kinerja perusahaan dapat dikatakan meningkat juga yang 
nantinya akan menyebabkan peningkatan harga saham karena semakin banyak investor yang tertarik untuk berinvestasi di perusahaan (Achiriyantiningsih, 2013).

Francis \& Schipper (1999) menyatakan bahwa pada penelitian terdahulu terjadi penurunan relevansi nilai informasi akuntansi dari waktu ke waktu. Lev (1989) menyatakan bahwa salah satu penyebab relevansi nilai laba turun ialah karena kualitas informasi akuntansi yang rendah. Rahman \& Oktaviana (2010) menyatakan bahwa manajemen laba menurunkan relevansi nilai laba maupun nilai buku. Manajemen laba yang dilakukan oleh manajer dapat menyesatkan pengguna laporan keuangan, sehingga menyebabkan respon investor terhadap informasi dalam laporan keuangan menjadi menurun. Selain itu, Collins et al., (1997) menyatakan bahwa penurunan relevansi nilai informasi akuntansi dari waktu ke waktu dijelaskan oleh meningkatnya proporsi perusahaan-perusahaan yang intangible-intensive dalam struktur industri, meningkatnya frekuensi laba negatif dan meningkatnya proporsi pos-pos laba tidak berulang dari waktu ke waktu. Namun penelitianPinasti (2004) membuktikan bahwa penurunan relevansi nilai dari waktu ke waktu ini tidak dapat diatribusikan kepada variabel industri, karakteristik laba negatif, maupun proporsi item laba tidak berulang.

Di Indonesia, sejak 1 Januari 2012 terjadi perubahan standar akuntansi keuangan, yaitu penerapan penuh standar akuntansi keuangan yang telah dikonvergensi dengan IFRS. Perubahan signifikan yang terjadi akibat pengadopsian IFRS adalah penggunaan nilai wajar dalam akuntansi. Penerapan IFRS ini diharapkan dapat mengurangi tindakan manajemen laba dan meningkatkan relevansi nilai informasi akuntansi setiap perusahaan (Ikatan 
Akuntan Indonesia). Hal ini didukung oleh penelitianDwiyanti (2017), (Abdullah et al., (2017), dan Ismawati et al., (2018), yang menunjukkan tingkat manajemen laba menjadi lebih kecil setelah mengadopsi IFRS. Selain itu,Garcia et al., (2016) melakukan penelitian mengenai pengaruh perubahan standar akuntansi berbasis internasional terhadap kualitas informasi di Amerika Latin. Hasil penelitian menunjukkan bahwa perubahan dari peraturan akuntansi lokal ke standar berbasis internasional meningkatkan relevansi nilai.

Penelitian-penelitian lain malah menemukan hasil yang berbeda.Baboukardos \& Rimmel(2016) melakukan penelitian mengenai relevansi nilai informasi akuntansi terhadap penerapan pelaporan terintegrasi (integrated reporting) di Johannesburg Stock Exchange (JSE). Hasil penelitian menunjukkan terjadi penurunan relevansi nilai informasi akuntansi. Selanjutnya,Astari \& Sukartha (2017) menyatakan bahwa terjadi penurunan relevansi nilai informasi akuntansi setelah diterapkannya IFRS. Hal ini mencerminkan bahwa keadaan di Indonesia yang belum mendukung peningkatan relevansi nilai informasi akuntansi yang diperoleh dengan diterapkannya IFRS. Penelitian lain menunjukkan bahwa pengadopsian penuh IFRS belum dapat meningkatkan relevansi nilai informasi akuntansi pada perusahaan yang termasuk indeks LQ45 di Bursa Efek Indonesia(Suhartono, 2018).

Rudra \& Bhattacharjee (2012), dalam penelitiannya menyatakan bahwa perusahaan di India yang menerapkan standar IFRS tidak dapat menurunkan tindakan manajemen laba. Hal ini dapat disimpulkan bahwa penyesuaian standar dengan mengadopsi IFRS belum menjamin adanya penurunan manajemen laba. 
Meskipun standar akuntansi dapat mengendalikan manajemen laba dalam beberapa kasus, tetapi belum berarti Negara yang mengadopsi standar akuntansi berkualitas akan memiliki informasi laporan keuangan yang berkualitas juga khususnya pelaporan tingkat manajemen laba yang rendah.

Manajemen laba merupakan salah satu faktor yang dapat mengurangi kredibilitas laporan keuangan, manajemen laba dapat menambah bias dalam laporan keuangan dan dapat mengganggu pemakai laporan keuangan yang mempercayai angka laba hasil rekayasa tersebut sebagai angka laba tanpa rekayasa(Setiawati \& Na'im, 2000). Barth et al., (2008) mengemukakan bahwa suatu informasi yang berkualitas diindikasikan oleh adanya hubungan yang kuat antara harga saham dengan laba serta nilai buku ekuitas. Manajemen laba dapat mempengaruhi keputusan investor, apabila investor menganggap sebagai suatu perilaku oportunis, maka investor akan bereaksi negatif yang dilihat dari turunnya relevansi nilai informasi akuntansi. Rahman \& Oktaviana(2010), menyatakan bahwa manajemen laba menurunkan relevansi nilai informasi akuntansi, baik untuk laba maupun nilai buku. Shan (2015) menyatakan bahwa dampak negatif dari relevansi nilai lebih besar bagi perusahaan yang terlibat dalam manajemen laba daripada perusahaan yang tidak terlibat dalam manajemen laba pada perusahaan yang terdaftar di Shanghai SSE 180 dan Shenzhen SSE 100.

Penelitian ini dilakukan pada perusahaan manufaktur yang terdaftar di Bursa Efek Indonesia periode 2012-2017. Periode waktu mulai tahun 2012 digunakan sebagai waktu penelitian karena sejak 1 Januari 2012 dimulainya penerapan standar IFRS. Perusahaan manufaktur dipilih sebagai lokasi penelitian karena 
perusahaan manufaktur memiliki cakupan lini produk yang lebih luas, yang memungkinkan manajemen laba bersifat lebih material dibandingkan dengan cakupan lini produk yang sempit dan perhitungan manajemen laba yang memang mencerminkan kondisi perusahaan manufaktur (Jones, 1991). Dari latar belakang tersebut, peneliti tertarik untuk melakukan penelitian mengenai manajemen laba dalam memoderasi pengaruh perubahan laba dan perubahan nilai buku ekuitas pada relevansi nilai informasi akuntansi.

Jensen \& Meckling(1976)menjelaskan bahwa hubungan agensi tejadi ketika satu orang atau lebih (principal) mempekerjakan orang lain (agent) untuk memberikan suatu jasa dan kemudian mendelegasikan wewenang pengambilan keputusan kepada agent. Pihak prinsipal memberi kewenangan kepada agen untuk melakukan transaksi atas nama prinsipal dan diharapkan akan membuat keputusan terbaik bagi prinsipalnya.

Beberapa penelitian mengenai relevansi nilai informasi akuntansi laba dilakukan oleh Rahman \& Oktaviana (2010), dan Bogstrand \& Larsson (2012), yang menyatakan bahwa laba memiliki relevansi nilai informasi akuntansi. Di Indonesia, jika IFRS diterapkan sesuai dengan ketentuan yang berlaku maka dapat menimbulkan dampak positif yaitu peningkatan relevansi nilai informasi akuntansi serta dapat mengurangi prilaku oportunistik manajemen. Hal ini karena penggunaan metode nilai wajar dalam IFRS lebih mencerminkan keadaan perusahaan yang sesungguhnya dibandingkan dengan penggunaan metode kos historis ketika IFRS belum diterapkan, sehingga perubahan laba berpengaruh positif pada relevansi nilai informasi akuntansi. 
Informasi perubahan laba digunakan oleh investor karena perubahan laba merupakan salah satu informasi yang digunakan dalam pertimbangan untuk melakukan investasi, sehingga ketika manajemen mengeluarkan informasi laba, investor akan merespon informasi tersebut yang dilihat dari perubahan harga saham. Informasi tersebut revan karena memiliki nilai prediksi, nilai umpan balik dan disajikan tepat waktu. Berdasarkan penjelasan tersebut, hipotesis pertama yang diajukan adalah:

$\mathrm{H}_{1}$ : Perubahan laba berpengaruh positif pada relevansi nilai informasi akuntansi.

Menurut teori keagenan, investor (prinsipal) memberi kewenangan kepada manajemen (agen) untuk melakukan transaksi atas nama prinsipal dan diharapkan akan membuat keputusan terbaik bagi prinsipalnya. Ketika manajemen menerbitkan informasi keuangan perusahaan, investor akan menggunakan informasi tersebut untuk dijadikan pertimbangan dalam melakukan investasi. Prinsipal (investor) akan merespon informasi apabila informasi yang disajikan oleh manajer (agen) dipercaya memiliki relevansi nilai.

Beberapa penelitian mengenai relevansi nilai informasi akuntansi atas nilai buku ekuitas dilakukan olehRahman dan Oktaviana (2010) dan Bogstrand et. al. (2012). Rahman dan Oktaviana (2010) menyatakan bahwa nilai buku ekuitas memiliki relevansi nilai informasi akuntansi. Bogstrand \& Larsson (2012)menyatakan bahwa relevansi nilai buku ekuitas meningkat setelah memberlakukan standar IFRS. Penerapan standar IFRS sesuai dengan ketentuan yang berlaku maka dapat menimbulkan dampak positif yaitu peningkatan relevansi nilai informasi akuntansi (Garcia et al., 2016). 
Investor akan melihat nilai buku ekuitas perusahaan untuk mengevaluasi kinerja pihak manajemen perusahaan. Apabila informasi yang diterbitkan oleh manajemen memiliki kualitas yang baik, maka investor akan merespon informasi tersebut dengan membeli atau mempertahankan saham yang dimilikinya, dimana respon tersebut akan diberikan jika para investor tersebut percaya bahwa informasi yang dirilis oleh pihak manajemen perusahaan tersebut memiliki nilai relevansi. Berdasarkan penjelasan tersebut, hipotesis kedua yang diajukan adalah: $\mathrm{H}_{2}$ : Perubahan nilai buku ekuitas berpengaruh positif pada relevansi nilai informasi akuntansi.

Jensen dan Meckling (1976) menjelaskan bahwa hubungan agensi tejadi ketika satu orang atau lebih (principal) mempekerjakan orang lain (agent) untuk memberikan suatu jasa dan kemudian mendelegasikan wewenang pengambilan keputusan kepada agent. Manajer sebagai agen lebih banyak memiliki informasi internal perusahaan dibandingkan dengan prinsipal, sehingga mengakibatkan agen akan memanfaatkan adanya asimetri informasi untuk menyembunyikan beberapa informasi yang tidak diketahui prinsipal. Diskresi yang dimiliki manajemen untuk melakukan penilaian dan memilih metode akuntansi bisa mempengaruhi besarnya akrual dan pada akhirnya mempengaruhi laporan keuangan.

Habib (2004); Rahman dan Oktaviani (2010) melakukan penelitian tentang pengaruh manajemen laba terhadap relevansi nilai nilai informasi akuntansi. Rahman dan Oktaviani (2010) menyatakan bahwa manajemen laba menurunkan relevansi nilai laba. Hal ini diakibatkan ketika perusahaan melakukan manajemen laba, ketidakpercayaan investor tidak hanya terletak pada angka laba yang dilaporkan, namun juga terhadap perusahaan secara keseluruhan. Habib (2004) 
yang mengkaji pengaruh manajemen laba terhadap relevansi nilai informasi akuntansi untuk data di pasar modal Jepang. Habib (2004) menyatakan bahwa jika investor menganggap manajemen laba sebagai suatu bentuk perilaku oportunis, sehingga investor akan bereaksi negatif. Hal ini dilihat dari turunnya relevansi nilai laba.

Informasi perubahan laba digunakan oleh investor untuk mempertimbangkan dalam melakukan keputusan investasi. Informasi laba ketika terindikasi adanya manajemen laba, maka informasi tersebut menjadi tidak relevan, karena laba tersebut tidak mencerminkan kondisi yang sebenarnya, sehingga manajemen laba memperlemah pengaruh perubahan laba pada relevansi nilai informasi akuntansi. Berdasarkan penjelasan tersebut, hipotesis ketiga yang diajukan adalah:

$\mathrm{H}_{3}$ : Manajemen laba memperlemah pengaruh perubahan laba pada relevansi nilai informasi akuntansi.

Jensen dan Meckling (1976) menjelaskan bahwa hubungan agensi tejadi ketika satu orang atau lebih (principal) mempekerjakan orang lain (agent) untuk memberikan suatu jasa dan kemudian mendelegasikan wewenang pengambilan keputusan kepada agent. Manajer sebagai agen lebih banyak memiliki informasi internal perusahaan dibandingkan dengan prinsipal, sehingga mengakibatkan agen akan memanfaatkan adanya asimetri informasi untuk menyembunyikan beberapa informasi yang tidak diketahui prinsipal. Diskresi yang dimiliki manajemen untuk melakukan penilaian dan memilih metode akuntansi bisa mempengaruhi besarnya akrual dan pada akhirnya mempengaruhi laporan keuangan. 
Penelitian yang dilakukan oleh Rahman dan Oktaviana (2010), menyatakan bahwa manajemen laba menurunkan relevansi nilai buku ekuitas. Hal ini diakibatkan ketika perusahaan melakukan manajemen laba, ketidakpercayaan investor tidak hanya terletak pada angka laba yang dilaporkan, namun juga terhadap perusahaan secara keseluruhan. Habib (2004) yang mengkaji pengaruh manajemen laba terhadap relevansi nilai informasi akuntansi untuk data di pasar modal Jepang. Habib (2004) menyatakan bahwa jika investor menganggap manajemen laba sebagai suatu bentuk perilaku oportunis, sehingga investor akan bereaksi negatif.

Manajemen laba yang tinggi mengindikasikan terdapat kecenderungan manajemen untuk secara oportunis memanipulasi laporan keuangan, sehingga manajeman laba bisa mengurangi relevansi nilai buku ekuitas. Manajemen laba yang bertujuan untuk memanipulasi laporan keuangan dapat menurunkan relevansi nilai buku ekuitas karena informasi tersebut dianggap tidak mencerminkan kondisi yang sebenarnya, sehingga investor bereaksi negatif. Berdasarkan penjelasan tersebut, hipotesis keempat yang diajukan adalah:

$\mathrm{H}_{4}$ : Manajemen laba memperlemah pengaruh perubahan nilai buku ekuitas pada relevansi nilai informasi akuntansi.

\section{METODE PENELITIAN}

Penelitian dilakukan pada perusahaan manufaktur yang terdaftar pada Bursa Efek Indonesia (BEI) pada tahun 2012-2017. Sedangkan Objek penelitian dalam penelitian ini adalah relevansi nilai informasi akuntansi. 
Relevansi nilai informasi akuntansi diukur dengan menggunakan modelOhlson(1995) dengan model harga. Model ini merupakan hubungan antara laba dan nilai buku pada harga saham yang digunakan untuk memperoleh nilai dari variabel relevansi nilai informasi akuntansi.Regresi linier berganda dilakukan untuk memperoleh koefisien masing-masing nilai EPS dan BVPS yang nantinya dimasukkan kedalam model Ohlson (1995) untuk memperoleh relevansi nilai informasi akuntansi tiap pengamatan sampel. Model Ohlson (1995) dapat rumuskan sebagai berikut :

$$
P i t=\alpha+\beta_{1} \text { EPSit }+\beta_{2} \text { BVPSit }+\varepsilon_{i t}
$$

Keterangan :

Pit = Harga per lembar saham perusahaan i pada saat tanggal publikasi laporan keuangan auditan tahun $\mathrm{t}$.

$\beta_{1}, \beta_{2}=$ Koefisien regresi dari masing-masing variabe independen

$E P S_{i t}=$ Laba per lembar saham perusahaan i pada akhir tahun $\mathrm{t}$

$B V P S_{i t}=$ Nilai buku per lembar saham perusahaan i pada akhir tahunt

$\alpha \quad=$ Konstanta

$\varepsilon \quad=$ Error Term, yaitu tingkat kesalahan penduga dalam penelitian

Earning per share menunjukkan kemampuan suatu perusahaan dalam menghasilkan laba untuk setiap saham yang dimiliki oleh investor (Hatta \& Dwiyanto, 2012). Rumus untuk menghitung EPS adalah sebagai berikut :

$$
E P S=\frac{\text { Laba Setelah Pajak }}{\text { Jumlah Saham Beredar }}
$$

Book value per share (BVPS) merupakan rasio yang digunakan untuk menunjukkan besarnya nilai riil suatu saham. Rumus yang digunakan untuk menghitung BVPS adalah sebagai berikut :

$$
\text { BVPS }=\frac{\text { Jumlah Ekuitas }}{\text { Jumlah Saham Beredar }}
$$


Pada penelitian ini menggunakan nilai perubahan laba yang didapat dengan rumus sebagai berikut :

$$
\Delta L a b a_{i t}=\frac{L a b a_{i t}-L a b a_{i t-1}}{L a b a_{i t-1}}
$$

Keterangan :

$\Delta$ Laba $_{\text {it }}=$ Perubahan laba perusahaan i tahun $\mathrm{t}$.

Laba $_{\text {it }} \quad=$ Laba bersih perusahaan $\mathrm{i}$ tahun $\mathrm{t}$.

Laba $_{\text {it }-1}=$ Laba bersih perusahaan $\mathrm{i}$ tahun $\mathrm{t}-1$.

Penelitian ini menggunakan perubahan nilai ekuitas yang didapat dengan rumus :

$$
\Delta \text { Ekuitas }_{i t}=\frac{\text { Ekuitas }_{i t}-\text { Ekuitas }_{i t-1}}{\text { Ekuitas }_{i t-1}}
$$

Keterangan :

$\Delta$ Ekuitas $_{\text {it }} \quad=$ Perubahan nilai ekuitas perusahaan $\mathrm{i}$ tahun $\mathrm{t}$.

Ekuitas $_{\text {it }} \quad=$ Nilai ekuitas perusahaan $\mathrm{i}$ tahun $\mathrm{t}$.

Ekuitas $_{\mathrm{it}-1}=$ Nilai ekuitas perusahaan $\mathrm{i}$ tahun $\mathrm{t}-1$.

Manajemen laba diproksikan oleh akrual diskresioner (discretionary accrual) yang diukur menggunakan model Jones modifikasi yang dikembangkan oleh Dechow et al., (1995). Akrual diskresioner merupakan perbedaan antara total akrual (TACC) dengan akrual nondiskresioner (nondiscretionary accrual NDACC). Tahap-tahap penentuan akrual diskresioner adalahmenghitung total akrual dengan menggunakan pendekatan aliran kas (cash flow approach), yaitu:

$$
\text { TACCit }=\text { EBXit }- \text { OCFit }
$$

Keterangan :

TACCit $=$ Total akrual perusahaan $\mathrm{i}$ pada tahun $\mathrm{t}$

EBXit $\quad=$ Laba bersih perusahaan i pada tahun $\mathrm{t}$

OCF it $\quad=$ Aliran kas dari operasi perusahaan i pada tahun $\mathrm{t}$ 
Langkah selanjutnya menentukan akrual nondiskresioner yaitu dengan melakukan regresi sebagai berikut:

$$
\frac{T A C C_{i t}}{T A_{i t-1}}=\beta_{1}\left(\frac{1}{T A_{i t-1}}\right)+\beta_{2}\left(\frac{\Delta R E V_{i t}-\Delta R E C_{i t}}{T A_{i t-1}}\right)+\beta_{3}\left(\frac{P P E_{i t}}{T A_{i t-1}}\right)+\varepsilon_{i t}
$$

Keterangan :

TACC $_{i t} \quad=$ Total akrual perusahaan i pada tahun $\mathrm{t}$

$T A_{i t-1} \quad=$ Total aset perusahaan i pada tahun $\mathrm{t}-1$

$\triangle R E V_{i t} \quad=$ Perubahan penjualan perusahaan i pada akhir tahun $\mathrm{t}$

$\triangle R E C_{i t} \quad=$ Perubahan piutang perusahaan i pada akhir tahun $\mathrm{t}$

$P P E_{i t} \quad=$ Aset tetap perusahaan $\mathrm{i}$ pada tahun $\mathrm{t}$

$\beta \quad=$ Koefisien regresi

Koefisien regresi $\beta 1, \beta 2$ dan $\beta 3$ digunakan untuk memprediksi akrual nondiskresioner melalui persamaan berikut:

$$
N D A C C_{i t}=\beta_{1}\left(\frac{1}{T A_{i t-1}}\right)+\beta_{2}\left(\frac{\Delta R E V_{i t}-\Delta R E C_{i t}}{T A_{i t-1}}\right)+\beta_{3}\left(\frac{P P E_{i t}}{T A_{i t-1}}\right)
$$

Keterangan :

NDACCit $=$ Akrual nondiskresioner perusahaan i pada tahun $\mathrm{t}$

Setelah didapatkan akrual nondiskresioner, kemudian akrual diskresioner bisa dihitung dengan mengurangkan total akrual dengan akrual nondiskresioner.

$$
D A C C_{i t}=\frac{T A C C_{i t}}{T A_{i t}}-N D A C C_{i t}
$$

Keterangan :

DACCit $=$ Akrual diskresioner perusahaan i pada tahun $\mathrm{t}$

Populasi dalam penelitian ini adalah seluruh perusahaan manufaktur yang terdaftar di Bursa Efek Indonesia (BEI) selama tahun 2012 - 2017. Periode waktu 
mulai tahun 2012 digunakan sebagai waktu penelitian karena sejak 1 Januari 2012 dimulainya penerapan standar IFRS.

Penelitian ini menggunakan teknik analisis regresi linier berganda dan Moderated Regression Analysys (MRA). Teknik analisis regresi linier berganda digunakan dalam menguji hipotesis pertama dan hipotesis kedua. Model ini mengggambarkan relevansi nilai informasi akuntansi sebagai fungsi nilai laba dan nilai buku ekuitas). Persamaan regresi tersebut adalah sebagai berikut:

$$
V R=\alpha+\beta_{1} \Delta \mathrm{Laba}+\beta_{2} \Delta \mathrm{NBE}+\varepsilon_{i t}
$$

Keterangan :

$V R=$ Relevansi nilai informasi akuntansi.

$\Delta$ Laba $=\quad$ Perubahan laba perusahaan i pada akhir tahun $\mathrm{t}$.

$\triangle \mathrm{NBE}=\quad$ Perubahan niilai buku ekuitas perusahaan i pada akhir tahun $\mathrm{t}$.

$\alpha=$ Konstanta

$\beta_{1}, \beta_{2}=$ Koefisien regresi dari masing-masing variabe independen

$\varepsilon \quad=\quad$ Error Term, yaitu tingkat kesalahan penduga dalam penelitian

Sedangkan model analisis yang digunakan dalam menguji hipotesis ketiga dan hipotesis keempat adalah analisis Uji Moderated Regression Analysys (MRA). Uji interaksi atau disebut MRA merupakan aplikasi khusus regresi linier berganda dimana dalam persamaan regresinya mengandung unsur interaksi (perkalian dua atau lebih variabel independen). Dalam kaitannya untuk menguji pengaruh perubahan laba dan perubahan nilai buku ekuitas dengan manajemen laba sebagai pemoderasi, maka model analisis yang dugunakan adalah sebagai berikut:

$V R=\alpha+\beta_{1} \Delta \mathrm{Laba}+\beta_{2} \Delta \mathrm{NBE}+\beta_{3} E M+\beta_{4} \Delta \mathrm{Laba} * \mathrm{EM}+\beta_{5} \Delta \mathrm{NBE} * \mathrm{EM}+\varepsilon_{i t}$ 
Keterangan :

$V R \quad=$ Relevansi nilai informasi akuntansi.

$\Delta \mathrm{Laba} \quad=$ Perubahan laba perusahaan i pada akhir tahun $\mathrm{t}$.

$\triangle \mathrm{NBE} \quad=$ Perubahan nilai buku ekuitas perusahaan i pada akhir tahun $\mathrm{t}$

$\beta_{1}-\beta_{5} \quad=$ Koefisien regresi dari masing-masing variabe independen.

$E M \quad=$ Manajemen laba.

$\Delta$ Laba $* \mathrm{EM}=$ Interaksi antara perubahan laba dengan manajemen laba.

$\triangle \mathrm{NBE} * \mathrm{EM}=$ Interaksi antara perubahan nilai buku ekuitas dengan manajemen laba.

$\varepsilon \quad=$ Error Term, yaitu tingkat kesalahan penduga dalam penelitian.

\section{HASIL DAN PEMBAHASAN}

Statistik deskriptif memberikan deskripsi suatu data yang dilihat dari nilai ratarata, standar deviasi, nilai maksimum, nilai minimum, yang digunakan untuk melihat kecenderungan dari masing-masing variabel penelitian. Hasil pengujian statistik deskriptif menggunakan program SPSS disajikan seperti pada Tabel 1.

Tabel 1.

Hasil Statistik Deskriptif

\begin{tabular}{llllll}
\hline & $\mathrm{N}$ & Minimum & Maksimum & Rata-rata & Standar Deviasi \\
\hline$\Delta$ Laba & 650 & $-50,091$ & 51,733 & $-0,311$ & 5,537 \\
$\Delta$ NBE & 650 & $-2,135$ & 7,011 & 0,115 & 0,415 \\
VR & 650 & $-3533,994$ & 8296,545 & 1799,989 & 1,490 \\
EM & 650 & $-8,531$ & 2,355 & 0,061 & 0,670 \\
Valid N (listwise) & 650 & & & & \\
\hline
\end{tabular}

Sumber: Data diolah, 2018

Berdasarkan Tabel 1variabel perubahan laba memiliki nilai rata-rata sebesar $-0,311$, standar deviasi sebesar 5,537. Nilai maksimum sebesar 51,733 yang dimiliki oleh PT Indospring Tbk. pada Tahun 2016. Nilai minimum sebesar 50,091 yang dimiliki oleh PT Multistrada Arah Sarana Tbk. pada Tahun 2015.

Variabel perubahan nilai buku ekuitas memiliki nilai rata-rata sebesar 0,115, standar deviasi sebesar 0,415 , nilai maksimum sebesar 7,011 yang dimiliki oleh 
PT SLI Global Tbk. pada tahun 2013, nilai minimum sebesar -2,135 yang dimiliki oleh PT SLI Global Tbk. pada tahun 2012.

Variabel relevansi nilai informasi akuntansi dalam penelitian ini diukur menggunakan model Ohlson (1995). Berdasarkan Tabel 1 variabel relevansi nilai informasi akuntansi memiliki nilai rata-rata sebesar 1.799,989, standar deviasi sebesar 1,490, nilai maksimum sebesar 8.296,545 yang dimiliki oleh PT Nipress Tbk. pada Tahun 2012, nilai minimum sebesar $-3.533,994$ yang dimiliki oleh PT Asia Pacific Fibers Tbk. pada Tahun 2017.

Variabel manajemen laba dalam penelitian ini diukur menggunakan model Jones modifikasi yang dikembangkan oleh Dechow et al. (1995). Berdasarkan Tabel 1 variabel manajemen laba memiliki nilai rata-rata sebesar 0,061 , standar deviasi sebesar 0,670, nilai maksimum sebesar 2,355 yang dimliki oleh PT Alumindo Light Metal Industry Tbk. pada Tahun 2013, nilai minimum sebesar 8,531 yang dimiliki oleh PT Kalbe Farma Tbk. pada Tahun 2013.

Selanjutnya dilakukan uji asumsi klasik yang meliputi uji normalitas, multikolinearitas, autokorelasi dan heterokedasitas. Uji yang pertama adalah uji normalitas. Berdasarkan hasil pengujian SPSS dapat dilihat bahwa nilai Kolmogorov Sminarnov (K-S) pada persamaan regresi berganda adalah sebesar 1,227, dengan nilai Asymp. Sig. (2-tailed) sebesar 0,098. Sedangkan nilai Kolmogorov Sminarnov (K-S) pada persamaan regresi moderasi adalah sebesar 1,356, dengan nilai Asymp. Sig. (2-tailed) sebesar 0,051. Hasil tersebut mengindikasikan bahwa model persamaan regresi berganda dan regresi moderasi 
tersebut berdistribusi normal karena nilai Asymp. Sig. (2-tailed) memiliki nilailebih besar dari alpha $=0,05$.

Uji asumsi klasik selanjutnya adalah uji multikolinearitas. Berdasarkan hasil uji multikolinieritas dapat dilihat bahwa untuk persamaan regresi berganda nilai tolerance pada masing-masing variabel lebih besar dari $10 \%$ atau 0,10 , demikian pula dengan nilai VIF masing-masing variabel kurang dari 10. Hal ini menunjukkan data yang digunakan dalam penelitian ini bebas dari gejala multikolinieritas.

Uji asumsi klasik selanjutnya adalah uji autokorelasi. Nilai DW pada persamaan regresi berganda adalah sebesar 2,072, nilai ini bila dibandingkan dengan nilai tabel signifikansi 5\%, jumlah sampel 650 (n) dan jumlah variabel independen $(\mathrm{K}=2)$ maka diperoleh nilai du 1,874. Nilai DW 2,072 lebih besar dari batas atas (du) yakni 1,874 dan kurang dari (4-du) 4-1,874 = 2,125, maka dapat disimpulkan bahwa tidak terdapat autokorelasi pada model persamaan regresi berganda.

Uji asumsi klasik selanjutnya adalah uji heterokedasitas. Berdasarkan hasil uji heterokedastisitas dapat dilihat bahwa nilai Sig. dari seluruh variabel memiliki nilai lebih besar dari 0,05 yang berarti tidak terdapat pengaruh antara variabel bebas terhadap absolute residual. Dengan demikian, model yang dibuat tidak mengandung gejala heteroskedastisitas.

Pengujian hipotesis pertama dan kedua dalam penelitian dilakukan dengan menggunakan analisis regresi linier berganda melalui software SPSS, diperoleh hasil yang disajikan pada Tabel 2: 
Tabel 2.

Hasil Analisis Regresi Linier Berganda

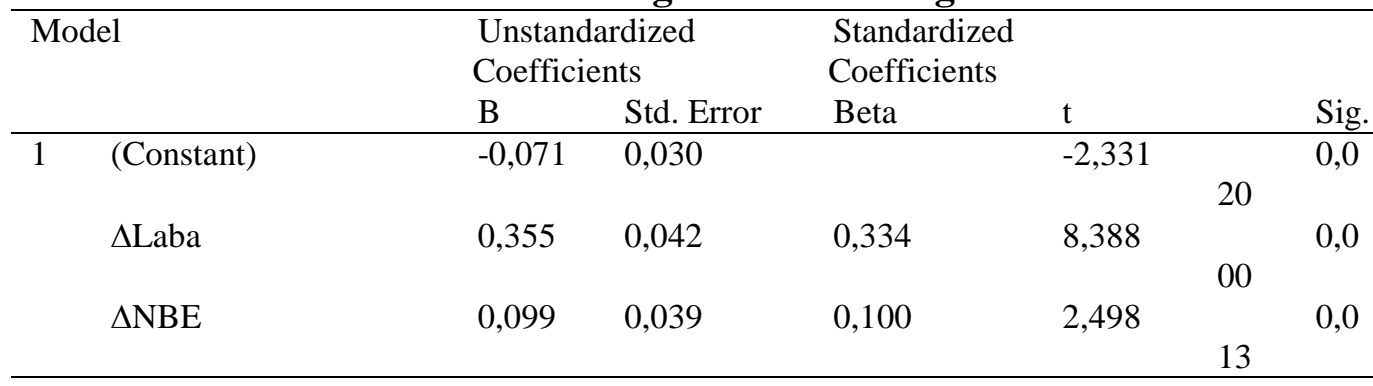

Sumber: Data diolah, 2018

Berdasarkan hasil analisis regresi linier berganda seperti yang disajikan pada Tabel 2, maka persamaan strukturalnya adalah sebagai berikut :

$$
\mathrm{VR}=-0,071+0,355 \Delta \mathrm{Laba}+0,099 \Delta \mathrm{NBE}+\mathrm{e}
$$

Nilai konstanta sebesar $-0,071$ memiliki arti apabila variabel independen perubahan laba dan perubahan nilai buku ekuitas bernilai konstan, maka variabel dependen relevansi nilai informasi akuntansi akan menurun sebesar 0,071.

Variabel perubahan laba memiliki koefisien regresi $\left(\beta_{1}\right)$ sebesar 0,355 , artinya apabila perubahan laba meningkat satu satuan maka relevansi nilai informasi akuntansi akan meningkat sebesar 0,355 dengan asumsi variabel independen lainnya konstan.

Variabel perubahan nilai buku ekuitas memiliki koefisien regresi $\left(\beta_{2}\right)$ sebesar 0,099, artinya apabila perubahan nilai buku ekuitas meningkat satu satuan maka relevansi nilai informasi akuntansi akan meningkat sebesar 0,099 dengan asumsi variabel independen lainnya konstan.

Pengujian hipotesis ketiga dan hipotesis keempat dalam penelitian ini menggunakan teknik analisis regresi moderasi (MRA). Perhitungan koefisien regresi moderasi dilakukan dengan analisis regresi moderasi melalui software SPSS, diperoleh hasil yang disajikan pada Tabel 3. 
Tabel 3.

Hasil Analisis Regresi MRA

\begin{tabular}{lllllll}
\hline Model & \multicolumn{4}{l}{ Unstandardized } & \multicolumn{2}{l}{ Standardized } \\
& & Coefficients & Coefficients & \\
& & $\mathrm{B}$ & Std. Error & Beta & $\mathrm{t}$ & Sig. \\
\hline 1 & (Constant) & $-0,073$ & 0,030 & & $-2,454$ & 0,014 \\
& $\Delta$ Laba & 0,206 & 0,048 & 0,194 & 4,315 & 0,000 \\
& $\Delta$ NBE & 0,046 & 0,039 & 0,046 & 1,167 & 0,244 \\
& EM & $-0,111$ & 0,043 & $-0,106$ & $-2,564$ & 0,011 \\
& $\Delta$ Laba*EM & $-0,097$ & 0,047 & $-0,089$ & $-2,077$ & 0,038 \\
& $\Delta$ NBE*EM & $-0,230$ & 0,044 & $-0,199$ & $-5,209$ & 0,000 \\
\hline
\end{tabular}

Sumber: Data diolah, 2018

Berdasarkan hasil analisis regresi moderasi seperti yang disajikan pada

Tabel 3, maka persamaan regresi yang dihasilkan adalah sebagai berikut :

$$
\begin{gathered}
\mathrm{VR}=-0,073+0,206 \Delta \mathrm{Laba}+0,046 \Delta \mathrm{NBE}-0,111 \mathrm{EM}-0,097 \Delta \mathrm{Laba}^{*} \mathrm{EM}- \\
0,230 \Delta \mathrm{NBE}^{*} \mathrm{EM}+\mathrm{e}
\end{gathered}
$$

Interaksi antara variabel perubahan laba dengan variabel manajemen laba $\left(\Delta\right.$ Laba*EM) memiliki koefisien regresi $\left(\beta_{4}\right)$ sebesar $-0,097$, artinya apabila moderasi manajemen laba meningkat satu satuan maka pengaruh perubahan laba pada relevansi nilai informasi akuntansi akan menurun sebesar -0,097 dengan asumsi variabel independen lainnya konstan.

Interaksi antara variabel perubahan nilai buku ekuitas dengan variabel manajemen laba $\left(\triangle \mathrm{NBE}^{*} \mathrm{EM}\right)$ memiliki koefisien regresi $\left(\beta_{5}\right)$ sebesar $-0,230$, artinya apabila moderasi manajemen laba meningkat satu satuan maka pengaruh perubahan nilai buku ekuitas pada relevansi nilai informasi akuntansi akan menurun sebesar -0,230 dengan asumsi variabel independen lainnya konstan.

Hasil uji koefisien determinasi pada model persamaan regresi berganda dalam penelitian ini disajikan dalam Tabel 4. 
Tabel 4.

Hasil Uji Koefisien Determinasi

\begin{tabular}{lll}
\hline Struktur & Persamaan & AdjustedR Square \\
\hline 1 & $\mathrm{VR}=-0,071+0,355 \Delta \mathrm{Laba}+0,099 \Delta \mathrm{NBE}+\mathrm{e}$ & 0,146 \\
2 & VR $=-0,073+0,206 \Delta \mathrm{Laba}+0,046 \Delta \mathrm{NBE}-0,111 \mathrm{EM}-$ & 0,203 \\
\hline
\end{tabular}

Sumber : Data diolah, 2018

Hasil uji koefisien determinasi pada analisis regresi linier berganda dalam

Tabel 4 menunjukkan bahwa nilai adjusted $\mathrm{R}^{2}$ adalah sebesar 0,146 . Ini berarti variasi dari relevansi nilai informasi akuntansi dipengaruhi oleh variabel perubahan laba dan nilai buku ekuitas sebesar 14,6 persen, sedangkan sisanya sebesar 85,4 persen dijelaskan oleh faktor-faktor lain.

Hasil uji koefisien determinasi pada model analisis regresi moderasi dalam Tabel 4 menunjukkan nilai adjusted $\mathrm{R}^{2}$ adalah sebesar 0,203 . Ini berarti variasi relevansi nilai informasi akuntansidapat dipengaruhi oleh variabel perubahan laba, perubahan nilai buku ekuitas, manajemen laba, interaksi antara variabel perubahan labadengan manajemen labadan interaksi antara variabel perubahan nilai buku ekuitasdenganmanajemen laba sebesar 20,3 persen, sedangkan sisanya sebesar 79,7 persen dijelaskan oleh faktor-faktor lain.

Uji kesesuaian model regresi bertujuan untuk mengetahui apakah semua variabel bebas yang meliputi perubahan laba, perubahan nilai buku ekuitas, manajemen laba, interaksi antaravariabel perubahan labadengan manajemen labaserta interaksi antara variabel perubahan nilai buku ekuitasdenganmanajemen laba tepat digunakan untuk memprediksi relevansi nilai informasi akuntansi. Uji ini dilakukan melalui pengujian uji $\mathrm{F}(F$ test $)$. 
Tabel 5.

Hasil Uji F

\begin{tabular}{llcc}
\hline Struktur & \multicolumn{1}{c}{ Persamaan } & F statistik & $\begin{array}{c}\text { Signifikansi } \\
\text { Uji F }\end{array}$ \\
\hline 1 & $\mathrm{VR}=-0,071+0,355 \Delta \mathrm{Laba}+0,099 \Delta \mathrm{NBE}+\mathrm{e}$ & 56,655 & 0,000 \\
2 & $\mathrm{VR}=-0,073+0,206 \Delta \mathrm{Laba}+0,046 \Delta \mathrm{NBE}-$ & 34,070 & 0,000 \\
& $0,111 \mathrm{EM}-0,097 \Delta \mathrm{Laba*EM}-0,230 \Delta \mathrm{NBE}$ EM $+\mathrm{e}$ & & \\
\hline
\end{tabular}

Hasil uji $\mathrm{F}$ ( $F$ test) dalam tabel 5 menunjukkan bahwa nilai signifikansi $\mathrm{P}$ value 0,000 pada hasil analisis regresi linier berganda maupun analisis regresi moderasi memiliki nilai yang lebih kecil dari $\alpha=0,05$, ini berarti model yang digunakan pada penelitian ini adalah layak. Hasil ini memberikan makna bahwa seluruh variabel independen yaitu perubahan laba, perubahan nilai buku ekuitas, manajemen laba, variabel interaksi antara perubahan labadengan manajemen labadan variabel interaksi antara perubahan nilai buku ekuitasdenganmanajemen laba mampu memprediksi atau menjelaskan fenomena relevansi nilai informasi akuntansi. Hal ini berarti model dapat digunakan untuk analisa lebih lanjut atau dengan kata lain model dapat digunakan untuk menjelaskan pengaruh variabel bebas pada variabel terikat, karena hasil goodness of fitnyaadalah sebesar nilai signifikansi P-value 0,000 yang lebih kecil dari $\alpha 0,05$.

Kriteria pengujian untuk menjelaskan interpretasi pengaruh antar masingmasing variabel yakni jika nilai signifikansi $<0,05$ maka $\mathrm{H}_{0}$ ditolak dan $\mathrm{H}_{1}$ diterima. Sebaliknya, jika nilai signifikansi > 0,05 maka $\mathrm{H}_{0}$ diterima dan $\mathrm{H}_{1}$ ditolak. Berdasarkan hasil analisis regresi linier berganda pada tabel 2 mengenai pengaruh perubahan labapada relevansi nilai informasi akuntansi diperoleh nilai signifikansi sebesar 0,000 dengan nilai koefisien regresi sebesar 0,355. Nilai Signifikansi $0,000<0,05$ mengindikasikan bahwa $\mathrm{H}_{0}$ ditolak dan $\mathrm{H}_{1}$ diterima. 
Hasil ini mempunyai arti bahwa perubahan laba berpengaruh positif dan signifikan pada relevansi nilai informasi akuntansi.Hasil penelitian ini sejalan dengan hasil penelitian sebelumnya yang dilakukan oleh Rahman dan Oktaviana (2010), Adhani \& Subroto (2014), dan Bogstrand \& Larsson (2012), yang menyatakan bahwa informasi laba memiliki relevansi nilai informasi akuntansi. Informasi perubahan laba dapat digunakan sebagai pertimbangan oleh investor dalam pengambilan keputusan investasi.Perubahan Laba memberikan informasi yang relevan bagi investor sebagai dasar pertimbangan keputusan berinvestasi. Informasi perubahan laba digunakan oleh investor karena perubahan laba merupakan salah satu informasi yang digunakan dalam pertimbangan untuk melakukan investasi, sehingga ketika manajemen mengeluarkan informasi laba, investor akan merespon informasi tersebut yang dilihat dari perubahan harga saham. Informasi tersebut relevan karena memiliki nilai prediksi, nilai umpan balik dan disajikan tepat waktu.

Berdasarkan hasil analisis regresi moderasi pada tabel 2 mengenai pengaruh perubahan nilai buku ekuitaspada relevansi nilai informasi akuntansi diperoleh nilai signifikansi sebesar 0,013 dengan nilai koefisien regresi sebesar 0,099. Nilai Signifikansi $0,013<0,05$ mengindikasikan bahwa $\mathrm{H}_{0}$ ditolak dan $\mathrm{H}_{2}$ diterima. Hasil ini mempunyai arti bahwa perubahan nilai buku ekuitas berpengaruh positif dan signifikan pada relevansi nilai informasi akuntansi.Hasil penelitian ini sejalan dengan hasil penelitian sebelumnya yang dilakukan oleh Rahman dan Oktaviana (2010), Adhani \& Subroto (2014), Agusti \& Rachman (2011), dan Bogstrand \& Larsson (2012)yang menyatakan bahwa informasi nilai buku ekuitas memiliki 
relevansi nilai informasi akuntansi. Selain itu, Pratiwi, et al., (2012) menyatakan bahwa nilai buku ekuitas merupakan faktor yang relevan dalam menjelaskan harga suatu sekuritas. Investor akan melihat nilai buku ekuitas perusahaan untuk mengevaluasi kinerja pihak manajemen perusahaan, dimana informasi nilai buku ekuitas yang diterbitkan oleh manajemen memiliki relevansi karena memiliki nilai prediksi, nilai umpan balik, serta disajikan tepat waktu.

Berdasarkan hasil analisis pengaruh perubahan labapada relevansi nilai informasi akuntansi dengan manajemen laba sebagai variabel moderasi pada Tabel 3 diperoleh nilai signifikansi sebesar 0,038 dengan nilai koefisien regresi sebesar -0,097. Hasil analisis regresi moderasi menunjukkan bahwa nilai koefisien regresi perubahan laba $\left(\beta_{1}\right)$ pada persamaan regresi linier berganda positif signifikan dan $\beta_{4}$ pada persamaan regresi MRA negatif signifikan, maka variabel manajemen laba merupakan variabel moderating yang memperlemah pengaruh perubahan laba pada relevansi nilai informasi akuntansi. Hal ini berarti bahwa manajemen laba memperlemah pengaruh positif perubahan laba pada relevansi nilai informasi akuntansi.Hasil penelitian ini sejalan dengan hasil penelitian sebelumnya yang dilakukan oleh Habib (2004), Rahman dan Oktaviana (2010), dan Shan (2015) yang menunjukkan bahwa manajemen laba menurunkan relevansi nilai laba. Para investor menganggap manajemen laba sebagai suatu bentuk perilaku oportunis yang menyebabkan investor akan bereaksi negatif, yang dilihat dari turunnya relevansi nilai laba. Ketika informasi akuntansi yang disajikan oleh manajemen terindikasi adanya manajemen laba, maka investor akan bereaksi negatif karena dianggap tidak mencerminkan kondisi yang sebenarnya. 
Berdasarkan hasil analisis pengaruh perubahan nilai buku ekuitaspada relevansi nilai informasi akuntansi dengan manajemen laba sebagai variabel moderasi pada Tabel 3 diperoleh nilai signifikansi sebesar 0,000 dengan nilai koefisien regresi sebesar -0,230. Hasil analisis regresi moderasi menunjukkan bahwa nilai koefisien regresi perubahan nilai buku ekuitas $\left(\beta_{2}\right)$ positif dan $\beta_{5}$ negatif signifikan, maka variabel manajemen laba merupakan variabel moderating yang memperlemah pengaruh positif perubahan nilai buku ekuitas pada relevansi nilai informasi akuntansi. Hasil penelitian ini sejalan dengan hasil penelitian sebelumnya yang dilakukan oleh Rahman dan Oktaviana (2010), dan Shan (2015) yang menunjukkan bahwa manajemen laba menurunkan relevansi nilai informasi atas nilai buku ekuitas. Hal ini berarti informasi perubahan nilai buku ekuitas terindikasi adanyakecenderungan manajemen untuk secara oportunis memanipulasi laporan keuangan, maka tindakan manajeman laba tersebut dapat mengurangi relevansi nilai buku ekuitas. Manajemen laba yang bertujuan untuk memanipulasi laporan keuangan dapat menurunkan relevansi nilai buku ekuitas karena informasi tersebut dianggap tidak mencerminkan kondisi yang sebenarnya, sehingga investor bereaksi negatif.

\section{SIMPULAN}

Penelitian ini bertujuan untuk menguji pengaruh perubahan laba dan nilai buku ekuitas pada relevansi nilai informasi akuntansi. Penelitian ini juga ingin membuktikan apakah manajemen laba dapat memoderasi pengaruh perubahan laba dan nilai buku ekuitas pada relevansi nilai informasi akuntansi. Berdasarkan 
hasil analisis, perubahan laba dan perubahan nilai buku ekuitas berpengaruh positif pada relevansi nilai informasi akuntansi. Selain itu, manajemen laba memperlemah pengaruh perubahan laba dan perubahan nilai buku ekuitas pada relevansi nilai informasi akuntansi. Perusahaan hendaknya menghindari tindakan manajemen laba yang bertujuan untuk mengatur laba yang dilaporkan agar sesuai dengan yang di inginkan. Tindakan manajemen laba dapat mengurangi kualitas informasi akuntansi, yaitu menurunnya relevansi nilai informasi akuntansi karena informasi tersebut dianggap tidak mencerminkan kondisi yang sebenarnya, sehingga investor menjadi tidak tertarik untuk melakukan investasi pada perusahaan tersebut.

Bagi para investor hendaknya mempertimbangkan perubahan laba, perubahan nilai buku ekuitas perusahaan, dan aktivitas manajemen laba sebagai pertimbangan dalam pengambilan keputusan investasi. Hal ini karena perubahan laba dan perubahan nilai buku ekuitas berpengaruh pada relevansi nilai informasi akuntansi. Selain itu, manajemen laba sebagai perilaku oportunis oleh manajemen dapat memperlemah relevansi nilai informasi atas laba dan nilai buku ekuitas.

Penelitian ini memiliki kekurangan yaitu mengeluarkan data outlier. Hal ini disebabkan karena data amatan pada penelitian ini hanya menggunakan perusahaan industri manufaktur. Penelitian selanjutnya disarankan untuk memperluas data amatan agar memungkinkan untuk melakukan analisis tanpa mengeluarkan data outlier, sehingga lebih mencerminkan kondisi populasi yang sebenarnya. 


\section{REFERENSI}

Abdullah, W. R. W., Maruhun, E. N. S., \& Tarmizi, M. A. (2017). The Adoption of IFRS and Earnings Management: Evidence from the Construction Industry in Malaysia. Proceedings of the Global Conference on Business and Economics Research.

Achiriyantiningsih, A. (2013). Pengaruh Debt to Equity Ratio (DER), Price Earning Ratio (PER), Net Saham Perusahaan Manufaktur Sub Sektor Barang Konsumsi yang Terdaftar Profit Margin (NPM) dan Book Value Per Share (BVPS) Terhadap Harga di Bursa Efek Indonesia (BEI) periode 2008-2012. Jurusan Akuntasi Fakultas Ekonomi Universitas Maritim Raja Ali Haji Tanjungpinang.

Adhani, Y. S., \& Subroto, B. (2014). Relevansi Nilai Informasi Akuntansi, Volume 2.N, 1-15.

Agusti, R. R., \& Rachman, A. F. (2011). Relevansi Informasi Akuntansi : Peran Pengungkapan Corporate Social Responsibility dan Dewan Komisaris Independen. Jaai, 15 no 2, 121-129.

Agustina, \& Silvia. (2012). Pengaruh Rasio Keuangan Terhadap Perubahan Laba Pada Perusahaan Manufaktur yang Terdaftar Di Bursa Efek Indonesia. Jurnal Wira Ekonomi Mikroskil, 2, 113-122.

Astari, N. P. E., \& Sukartha, I. M. (2017). Relevansi Nilai Informasi Akuntansi Serta Manajemen Laba Sebelum Dan Sesudah Penerapan International Financial Reporting Standard. E-Jurnal Akuntansi Universitas Udayana, 21(2), 1290-1316.

Baboukardos, D., \& Rimmel, G. (2016). Value Relevance of Accounting Information Under An Integrated Reporting Approach: A research note. Journal Of Accounting And Public Policy. https://doi.org/10.1016/j.jaccpubpol.2016.04.004

Barth, M. E., Beaver, W. H., \& Landsman, W. R. (2001). The relevance of the value relevance literature for financial accounting standard setting: another view. Journal of Accounting and Economics, 31, 77-104.

Barth, M. E., Landsman, W. R., \& Lang, M. H. (2008). International Accounting Standards and Accounting Quality. Journal OfAccounting Research, 46(3). https://doi.org/10.1111/j.1475-679X.2008.00287.x

Bogstrand, O., \& Larsson, E. A. (2012). Have IFRS Contributed to an Increased Value-Relevance? UPPSALA University-Departement OfBusiness Studies, (1606), 1-33. 
Collins, D. W., Maydew, E. L., \& Weis, I. S. (1997). Changes in the ValueRelevance of Earnings and Book Values over the Past Forty Years. Journal of Accounting and Economics 24, 39-67. https://doi.org/10.1016/S01654101(97)00015-3

Dechow, P. M., Sloan, R. G., \& Sweeney, A. P. (1995). Detecting Earnings Management. The Accounting Review, Vol. 70, N, 193-225.

Dwiyanti, K. T. (2017). Pengadopsian Standar Akuntansi Berbasis Ifrs , Kepemilikan Keluarga , Dan Manajemen Laba. Jurnal Ilmiah Akuntansi Dan Bisnis, $12(2)$, 65-73. https://doi.org/https://doi.org/10.24843/JIAB.2017.v12.i02.p01

Francis, J., \& Schipper, K. (1999). Have Financial Statements Lost Their Relevance ?, 37(2), 319-352.

Garcia, M. del P. R., Alejandro, K. A. C., Saenz, A. B. M., \& Sanchez, H. H. G. (2016). Does an IFRS adoption increase value relevance and earnings timeliness in Latin America? Emerging Markets Review, S15660141(16)30135-2. https://doi.org/10.1016/j.ememar.2016.11.001

Habib, A. (2004). Impact of Earnings Management on Value-Relevance of Accounting Information: Empirical Evidence from Japan. Managerial Finance, 30(11), 1-15. https://doi.org/http://dx.doi.org/10.1108/03074350410769344

Hatta, A. J., \& Dwiyanto, B. S. (2012). The Company Fundamental Factors And Systematic Risk In Incerasing Stock Price. Journal of Economics, Business, and Accountancy Ventura, 15(110), 245-256.

Ismawati, Yuliana, R., \& Rimawati, Y. (2018). Adopsi IFRS dan Pengaruhnya Terhadap Manajemen Laba Akrual dan Manajemen Laba Riil Pada Perusahaan Manufaktur Di Bursa Efek Indonesia. Jurnal InFestasi, 14(1), 69-79.

Jensen, M. C., \& Meckling, W. H. (1976). ). Theory of The Firm: Managerial Behavior, Agency Cost and Ownership Structure. Journal of Financial Economics, 3, 305-360.

Jones, J. J. (1991). Earnings Management During Import Relief Investigations, $29(2)$.

Kargin, S. (2013). The Impact of IFRS on the Value Relevance of Accounting Information: Evidence from Turkish Firms. International Journal of Economics and Finance, 5(4). https://doi.org/10.5539/ijef.v5n4p71 
Kusuma, H. (2006). Dampak Manajemen Laba terhadap Relevansi Informasi Akuntansi : Bukti Empiris dari Indonesia. Jurnal Akuntansi Dan Keuangan, $8(1), 1-12$.

Lev, B. (1989). On the Usefulness of Earnings and Earnings Research : Lessons and Directions from Two Decades of Empirical Research. Journal of Accounting Research, 27(3), 153-193.

Ohlson, J. A. (1995). Eamings, Book Values, and Dividends in Equity Valuation. Contemporary Accounting Research, 11(2), 661-687.

Pinasti, M. (2004). Faktor-Faktor Yang Menjelaskan Variasi Relevansi-Nilai Informasi Akuntansi: Pengujian Hipotesis Informasi Alternatif. Simposium Nasional Akuntansi VII, 738-753.

Pratiwi, E., Indriani, R., \& Midiastuty, P. P. (2012). Relevansi Nilai Informasi Laporan Keuangan Dan Komponen Laba Rugi Komprehensif Dalam Menjelaskan Harga Dan Return Saham. Prosiding Seminar Nasional.

Rahman, A. F., \& Oktaviana, U. K. (2010). Masalah Keagenan Aliran Kas Bebas, Manajemen Laba dan Relevansi Nilai Informasi Akuntansi. Simposium Nasional Akuntansi XIII.

Rudra, T., \& Bhattacharjee, C. D. (2012). Does IFRs Influence Earnings Management? Evidence from India. Journal of Management Research, 4(1), 1-13. https://doi.org/10.5296/jmr.v4i1.849

Setiawati, L., \& Na'im, A. (2000). Manajemen Laba. Jurnal Ekonomi Dan Bisnis Indonesia, 15(4), 424-441.

Shan, Y. G. (2015). Value relevance, earnings management and corporate governance in China Yuan. Emerging Markets Review. https://doi.org/10.1016/j.ememar.2015.04.009

Suhartono, S. (2018). Analisis komparasi relevansi nilai informasi akuntansi sebelum dan sesudah adopsi penuh ifrs di indonesia, 11(1), 68-81.

Suwardjono. (2017). Teori Akuntansi: Perekayasaan Pelaporan Keuangan (Edisi Keti). Yogyakarta: BPFE. 